\title{
The Effect of Walnut on the Weight, Blood Glucose and Sex Hormones of Diabetic Male Rats
}

\author{
Efecto del Nogal sobre el Peso, Glucosa en la Sangre \\ y Hormonas Sexuales de Ratas Macho Diabéticas
}

Ghorbani, R."; Mokhtari, T.**; Khazaei, M.*; Salahshoor, M. R."; Jalili, C.. \& Bakhtiari, M.**

GHORBANI, R.; MOKHTARI, T.; KHAZAEI, M.; SALAHSHOOR, M. R; JALILI, C \& BAKHTIARI, M. The effect of walnut on the weight, blood glucose and sex hormones of diabetic male rats. Int. J. Morphol., 32(3):833-838, 2014.

SUMMARY: Diabetes leads to reproductive dysfunctions by producing free radicals. It seems that using walnut can be effective in the damage induced by diabetes. The aim of the present study was to evaluate the effects of walnut consumption on sex hormones in diabetic Wistar male rats induced by STZ (streptozotocin). Diabetes animals were induced by STZ (60 mg/kg). Rats were randomly divided into 5 groups $(n=6)$, including normal diet and healthy (Sham), Diabetic by normal diet (control) and diabetic by 6,9 and $12 \%$ walnut in their diet (experimental groups), and were examined for 6 weeks. Body weight, blood glucose (3 times), and sex hormones (testosterone, FSH and LH) were measured. Overall, in terms of the mean index, there was a significant difference in the percentage of weight changes between the groups $(\mathrm{p}<0.001)$. Blood glucose (3 times) significantly increased in experimental and control groups in comparison with sham group $(\mathrm{p}<0.001)$. FSH concentration significantly decreased in control group $(\mathrm{p}<0.05)$ and testosterone hormone decreased in experimental and control groups compared to sham group $(\mathrm{p}<0.05)$. Oral administration of walnut seems to prevent severe weight loss in the experimental models of diabetic rats and exerts appropriate and useful changes in blood glucose level as well as positive effects on the secretion of sex hormones.

KEY WORDS: Walnut; Diabetes; Weight; Blood glucose; Sex hormones.

\section{INTRODUCTION}

Diabetes is the most common endocrine disorder characterized by hyperglycemia and Carbohydrate, fat and protein metabolism disorder (Williams \& Pickup, 2004). According to the census of World Health Organization (WHO) in 2008, nearly 246 million people suffer from diabetes. It is estimated that this figure reach 380 million by 2050. About $90 \%$ of the diabetic patients have sexual dysfunctions in the form of reduction in sexual derive and fertility (Pereira et al., 2007).

Testis function is, at first, controlled by hypophysis hormones. The follicle-stimulating hormone (FSH) regulates spermatogenesis whereas; luteinizing hormone $(\mathrm{LH})$ controls the performance of interstitial cells (Ward et al., 1991). FSH is a crucial factor in the development of testis, performance of sustentacular cells, and protection of normal spermatogenesis. Also, the hypophysis of diabetic rats is affected by the reduction in response along with reduction in FSH and LH levels (Seethalakshmi et al., 1987). These findings indicate that there is an association between insulin/ glucose level and FSH/LH level in plasma. Diabetes mellitus induces changes in the testis tissue via apoptosis, atrophy of seminiferous tubules, decreasing tubules' diameter, and declining spermatogenic cells (Zhang et al., 2009).

Streptozotocine (STZ) is an antibiotic used for the treatment of the carcinoma of the islets of Langerhans, which causes an increase in blood sugar and induction of diabetes by damaging beta cells (Martinez et al., 2006). This drug causes oxidative damage to germ cell, and the produced ROS can induce testis dysfunctions and lead to infertility. Diabetes mellitus in STZ-induced diabetic rats affects testis performance through FSH/LH-related mechanisms (Prasad et al., 2003).

The presence of antioxidants such as vitamins and flavonoids in the diet can have protective effects in diabetic patients. Walnut contains more than 10 antioxidants and is ranked second from among 1113 food supplies containing

\footnotetext{
* Fertility and Infertility Research Center, Kermanshah University of Medical Sciences, Kermanshah, Iran.

** Anatomy Department, Kermanshah University of Medical Sciences, Kermanshah, Iran.
} 
antioxidant (Zhang et al.). In a study, phenol compounds were extracted from walnut. It was reported that these compounds have antioxidant property and most of them are taken from phenolic acid and tannins (Lavedrine et al., 2000). It has been reported that walnut diet in the society afflicted with hyperlipidemia can induce significant changes in lipid diffusion and various kinds of lipoproteins, even though the total plasma lipid (TPL) is not changed (Fukuda et al., 2003).

Some authors indicated that walnut extract as a substance full of antioxidant can prevent the poisoning induced in rats' testes (Labuckas et al., 2008). The effect of polyphenols extracted from walnut on the oxidative stress induced by diabetes type 2 was investigated in the rats and was shown that this substance has antioxidant effects, both in vivo and in vitro. Further, oral consumption of walnut increased melatonin and total antioxidant capacity in the blood (Lavedrine et al.).

Since there has been no report on the therapeutic effect of walnut on the reproductive dysfunctions induced by diabetes, the present research was conducted to examine the effect of walnut on the dysfunctions created in the sex hormones by STZ-induced diabetes in Wistar male rats.

\section{MATERIAL AND METHOD}

Forty Wistar male rats with the average age of 13 weeks and the weight range of 200-250 g were purchased (Razi institute, Iran). One week before the start of the experiment, were kept in the animal house under laboratory conditions, temperature of $20 \pm 2$ and 12/12 day/light, to be adapted to the environment. The rats in the control group had unlimited access to water and food. In the groups with walnut diet, the food mixed with walnut powder in the rats' intended proportions $(6,9$ and 12 percent based on the weight proportion) was placed in the metal cages, and one rat was kept in each cage. The study lasted for 6 weeks (KrisEtherton et al., 1999).

To induce diabetes in the rats, streptozotocine (Sigma), was administered intraperitoneally (ip) $(60 \mathrm{mg} / \mathrm{kg})$. Three days after administration, blood was taken from the rats' cauda to ensure the rats have become diabetic. The animals whose blood glucose was more than $300 \mathrm{mg} / \mathrm{dl}$ were considered as diabetic. Blood glucose was measured three times: 1) after STZ injection to assure being diabetic, 2) three weeks after first injection, 3) six weeks after first injection. The animals' weight was measured at the beginning and end of the study. The changes in animals' weight in each group were computed via the following formula:
Weight changes $=($ Animal's weight at the end of the study - animal's weight at the beginning of the study) / (Animal's weight at the end of the study + animal's weight at the beginning of the study) x 100 .

Serum glucose level was measured before STZ administration, three days after administration to ensure being diabetic, and during weeks 3 and 6. Glucose oxidase (GOD-PAP) method was used to determine blood glucose concentration (Anderson et al., 2001).

To prepare the special food containing walnut, the Iranian walnut (Twiserkani) was prepared from the local market and approved scientifically based on the morphological characteristics. The powder obtained from grinding the walnut was mixed with the rat's standard food in proportions of 6,9 and 12 percent. The pelleted food was made again by the food processor at medical faculty (KrisEtherton et al.).

The rats' cauda was used to measure blood glucose (Anderson et al.). The rats were randomly assigned to five groups ( $\mathrm{n}=6)$ (15): 1) diabetic with normal diet (Sham), 2) diabetic with normal diet (control), 3) diabetic with walnut $(6 \%)$ diet, 4) diabetic with walnut $(9 \%)$ diet, 5) diabetic with walnut (12\%) diet.

After 6 weeks, the rats were deeply anesthetized with chloroform. The required blood was immediately taken from the ventricle for testing the hormones. Both of testes were extracted, the left testis was used for the analysis of sperm parameters and the right testis was placed in the Bouin's fixative for histological analyses. The sperm parameters were determined according to WHO instructions. To do so, after separating epididymis from testis (using stereo microscope), sampling was carried out from the cauda end to vas deferens in all samples. To prepare histological slides from the testes, the testes' height was measured by YATO digital caliper. The testes were divided into two equal parts, were fixed in the Bouin solution, and $5 \mu \mathrm{m}$ slides were serially prepared according to common paraffin method. Slides 5, 10, 15, 20, and 25 in each testis were stained by H\&E method and analyzed morphologically (Bancroft \& Marilyn, 2002).

\section{RESULTS}

Weight changes. The findings indicated differences in the mean index in terms of the percentage of the weight changes between groups $[f(4,20)=7.637, p<0.001]$.

The post hoc analysis showed a significant difference 
between sham and control groups, diabetic and diabetic with $6 \%$ walnut diet, diabetic and $9 \%$ walnut diet, and diabetic and $12 \%$ walnut diet $(\mathrm{p}<0.001)$ (Fig. 1).

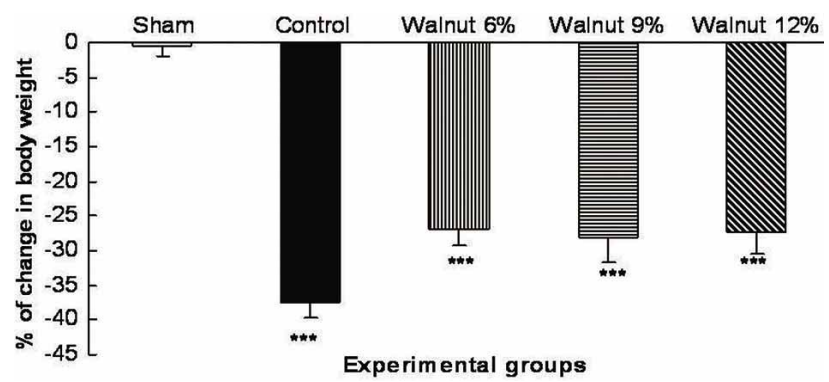

Fig. 1. Comparison of the mean of weight changes (\%) in different groups.

*** Significant difference between sham and control groups, diabetic and diabetic with $6 \%$ walnut diet, diabetic and $9 \%$ walnut diet, and diabetic and $12 \%$ walnut diet $(\mathrm{p}<0.001)$.

Blood glucose. The results indicated significant differences between groups in the first, second and third times of blood glucose measurement $[\mathrm{f}(4,20)=39.045, \mathrm{p}<0.001]$, [f(4,20) $=40.785, \mathrm{p}<0.001]$, and $[\mathrm{f}(4,20)=14.220, \mathrm{p}<0.001]$, respectively.

However, the post hoc analysis showed that this difference was significant in the first time between sham and control groups, diabetic and diabetic with normal diet, diabetic and $6 \%$ walnut diet, diabetic and $9 \%$ walnut diet, and diabetic and $12 \%$ walnut diet $(\mathrm{p}<0.001)$. Further, there was a significant difference between diabetic and $6 \%$ walnut diet groups, and diabetic and $12 \%$ walnut diet groups $(\mathrm{p}<0.05)$ (Fig. 2).

Also, the post hoc analysis indicated this significant difference in the second time between sham and control groups, diabetic and normal diet, diabetic and $6 \%$ walnut diet, diabetic and 9\% walnut diet, and diabetic and $12 \%$ walnut diet ( $\mathrm{p}<0.001)$ (Fig. 2).

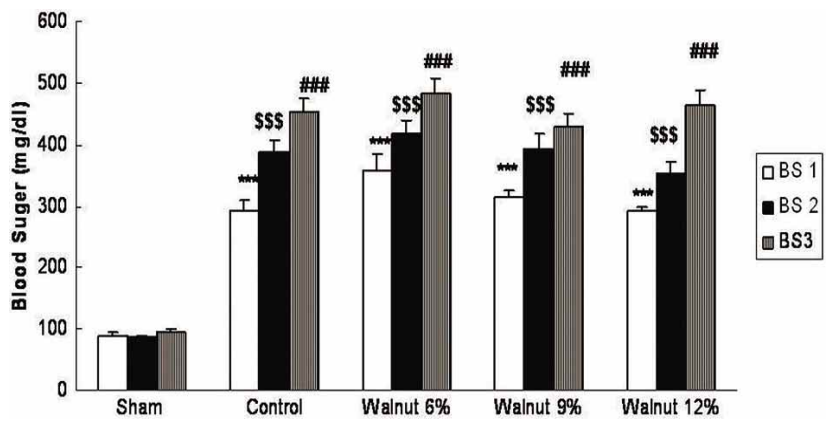

Fig. 2. Various percentages of walnut serum FSH.

*Significant difference between sham and control groups $(\mathrm{p}<0.05)$.
Moreover, the post hoc analysis demonstrated this significant difference in the third time between sham and control groups, diabetic and normal diet, diabetic and $6 \%$ walnut diet, diabetic and $9 \%$ walnut diet, and diabetic and $12 \%$ walnut diet $(\mathrm{p}<0.001)$ (Fig. 2).

In addition, the post hoc analysis indicated this difference in the third time between sham and control group $(\mathrm{p}<0.05)$, and diabetic and normal diet, diabetic and $6 \%$ walnut diet, diabetic and $9 \%$ walnut diet, and diabetic and $12 \%$ walnut diet $(\mathrm{p}<0.001)$ (Fig. 3).

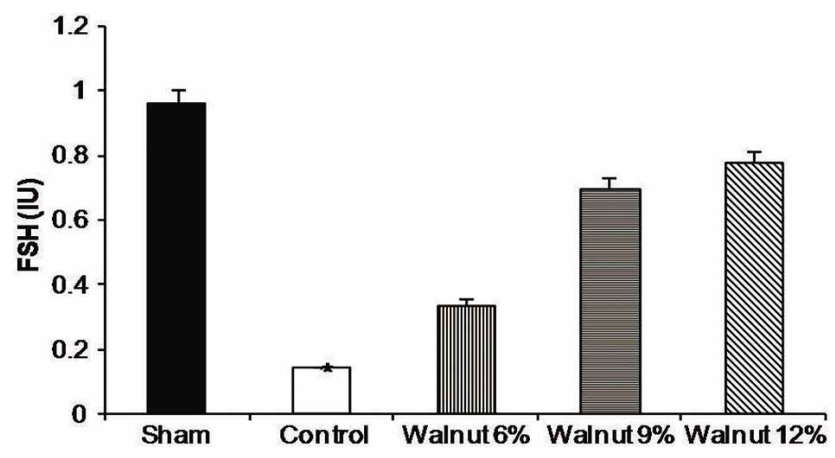

Fig. 3. Comparison of the means of blood glucose in the three times for different groups.

*** Significant difference between sham and control groups, diabetic and normal diet, diabetic and diabetic with $6 \%$ walnut diet, diabetic and $9 \%$ walnut diet, and diabetic and $12 \%$ walnut diet $(\mathrm{p}<0.001) \$ \$ \$$ Significant difference between sham and control groups, diabetic and normal diet, diabetic and diabetic with $6 \%$ walnut diet, diabetic and $9 \%$ walnut diet, and diabetic and $12 \%$ walnut diet $(\mathrm{p}<0.001) \# \# \#$ Significant difference between sham and control groups, diabetic and normal diet, diabetic and diabetic with $6 \%$ walnut diet,diabetic and $9 \%$ walnut diet, and diabetic and $12 \%$ walnut diet $(\mathrm{p}<0.001)$.

\section{Serum hormones' level}

1. FSH Serum: FSH concentration was determined in one part of the study. The results showed a significant difference in serum FSH concentration $[\mathrm{f}(4,20)=.831, \mathrm{p}<0.05]$. However, the post hoc analysis indicated this significant difference between sham and control groups $(\mathrm{p}<0.05)$.

2. LH: The LH level was determined in another part of the study. The findings indicated no significant difference in the LH level between various groups (Fig. 4).

3. Testosterone. The results revealed that serum testosterone concentration was different in various groups $[\mathrm{f}(4,20)=$ $8.009, \mathrm{p}<0.05]$. The post hoc analysis, however, indicated that this difference was significant between sham and control groups, diabetic and diabetic with $6 \%$ walnut diet, diabetic and $9 \%$ walnut diet, and diabetic and $12 \%$ walnut $\operatorname{diet}(\mathrm{p}<0.05)$ (Fig. 5). 


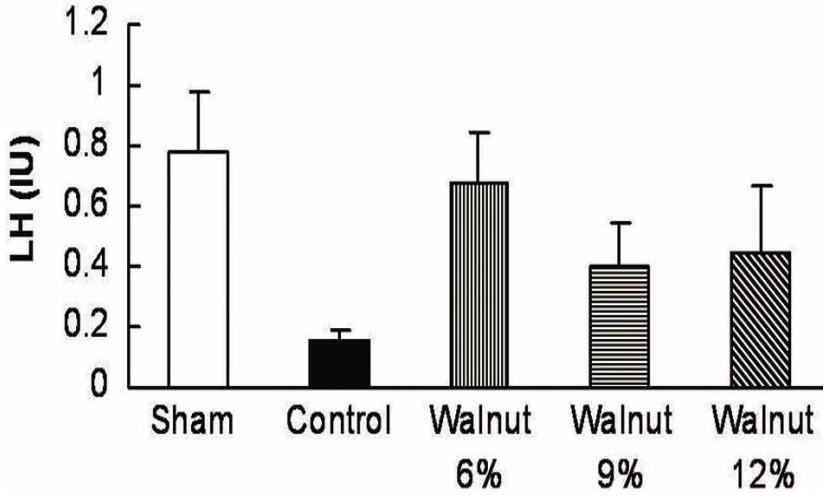

Fig. 4. Various percentages of walnut in serum LH.

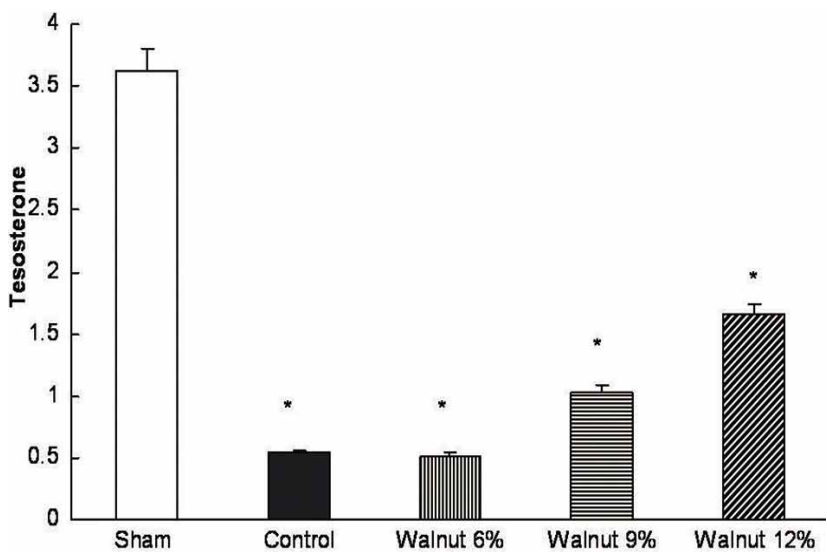

Fig. 5. Different percentages of walnut in serum testosterone hormone.

*** Significant difference between sham and control groups, diabetic and diabetic with $6 \%$ walnut diet, diabetic and $9 \%$ walnut diet, and diabetic and $12 \%$ walnut diet $(\mathrm{p}<0.05)$.

\section{DISCUSSION}

Melatonin as pineal hormone plays a basic role in the preservation of testis against oxidative stress. The significant inductive effect of this hormone after removing pineal gland and inducing oxidative damages has been reported in the testis (Mogulkoc et al., 2006). In recent studies on walnut, ellagic acid, gallic acid, and flavonoids have been extracted, which prevent the in vivo oxidation of human plasma and LDL (Anderson et al.). Although the exact mechanisms of diabetes mellitus have not been recognized, increasing the production of free radicals is considered as the destructive mechanisms of this disease (Palmeira et al., 2001). The findings obtained from this study indicated that the percentage of weight changes significantly decreased in both control and diabetic groups compared to sham group. Administration of STZ caused symptoms such as polydipsia, polyuria, weight loss, and hyperglycemia (Golalipour et al., 2013; Komolafe et al., 2013), which is in line with the results of this study (Shenoy \& Goyal, 2002). Based on the results of the previous studies, STZ administration decreases the rats' weight due to diabetes induction. This is compatible with the results of this study, while comparing control and sham groups (Kianifard et al., 2011). In spite of the increasing changes, no significant difference was observed in the experimental groups compared to control group. This indicates that walnut contains high levels of fatty compounds.

The findings of the present study demonstrated that glucose had significant increase in the experimental and control groups in different times compared to sham group. This difference indicates that walnut has not had a positive effect on blood glucose. According to previous studies, STZ is used to induce diabetes type 1 (Golalipour et al.; Komolafe et al.). As in other studies, increasing blood glucose in control group was observed in this study as well (Kim et al., 2003). Consuming walnut as a diet in (Ma et al., 2010) study decreased serum glucose in comparison with other groups, but it was not significant, as in this study. Further, serum FSH level was analyzed in this study. The results indicated a significant decrease in the serum level in the control group compared to sham group. The results of (Maneesh et al., 2003) showed that diabetes affects hypothalamic hypophyseal gonadal axis in men and significantly decreases FSH, which is similar to the results of this study. Moreover, diabetes mellitus affects hypothalamic hypophyseal gonadal axis in men and significantly decreases FSH, which is in line with the results of this study (Stanciu et al., 2010).

In the present study, no significant difference was found between experimental groups and sham group. Also, significant difference was not observed between experimental groups and control group, which indicates that walnut consumption, can positively affect FSH secretion dysfunction induced by diabetes. This can be attributed to the existence of melatonin and other existing antioxidants.

Further, serum LH level measured in the control group decreased in comparison with sham group, but it was not significant. Diabetes affects hypothalamic hypophyseal gonadal axis in men and significantly decreases LH (Maneesh et al.). Diabetes mellitus affects hypothalamic hypophyseal gonadal axis in men and prevents changes in $\mathrm{LH}$, which is in line with the findings of this study (Stanciu et al.). Also, the increase of this hormone in experimental groups, indicated in Graph 4, was not significant, which can be due to the presence of melatonin and other present antioxidants. There was a significant decrease in the 
testosterone level between experimental and control groups, and sham group, but the graph demonstrates a slight increase in the experimental groups compared to control group, which is not significant. Based on the present research, injection of high doses of STZ decreases testosterone level which is due to the impact on interstitial cells. This was observed in the present study, too. Further, demonstrated diabetes influences male hypothalamic hypophyseal gonadal axis and significantly decreases testosterone, which is similar to the results of this study (Maneesh et al.).

The results showed that diabetes mellitus affects male hypothalamic hypophyseal gonadal axis and significantly decreases testosterone, which is similar to the results of this study (Stanciu et al.). STZ causes a decrease in interstitial cells in testis and consequently causes infertility in rats (Paz
\& Homonnai, 1979). No change was also observed in LH receptors on interstitial cells.

\section{CONCLUSION}

The present study indicated that diabetes induces destructive effects on the secretion of sex hormones and walnut exerts significant positive impacts on the secretion of sex hormones disrupted by diabetes, including FSH secretion.

ACKNOWLEDGEMENTS. This study was supported by University of Kermanshah-Iran.

GHORBANI, R.; MOKHTARI, T.; KHAZAEI, M.; SALAHSHOOR, M. R; JALILI, C \& BAKHTIARI, M. Efecto del nogal sobre el peso, glucosa en la sangre y hormonas sexuales de ratas macho diabéticas. Int. J. Morphol., 32(3):833-838, 2014.

RESUMEN: La diabetes conduce a disfunciones reproductivas mediante la producción de radicales libres. Parece que el uso del nogal puede ser eficaz para contrarestar el daño inducido por la diabetes. El objetivo fue evaluar los efectos del consumo de nueces sobre las hormonas sexuales en ratas Wistar macho diabéticas, inducidas por estreptozotocina (STZ). La diabetes en los animales fue inducida por STZ $(60 \mathrm{mg} / \mathrm{kg})$. Los animales fueron divididos aleatoriamente en 5 grupos $(\mathrm{n}=6)$ ): saludable con dieta normal (Sham), diabéticos con dieta normal (control) y diabéticos con consumo de nogal en 6,9 y $12 \%$ en su dieta (grupos experimentales), quienes se examinaron durante 6 semanas, donde se midieron el peso corporal, glucosa en la sangre (3 veces) y hormonas sexuales (testosterona, FSH y LH). En general, en términos del índice promedio, hubo una diferencia significativa en el porcentaje de cambios de peso entre los grupos ( $\mathrm{p}<0,001$ ). La glucosa en sangre aumentó significativamente en los grupos experimentales y de control en comparación con el grupo Sham ( $\mathrm{p}<0,001$ ). La concentración de FSH se redujo significativamente en el grupo control ( $p<0,05)$; la testosterona disminuyó en los grupos experimentales y control en comparación con el grupo sham $(\mathrm{p}<0,05)$. La administración oral de nogal parece prevenir la pérdida severa de peso en los modelos experimentales de ratas diabéticas y ejerce cambios apropiados y útiles en el nivel de glucosa en la sangre, así como efectos positivos sobre la secreción de hormonas sexuales.

PALABRAS CLAVE: Nogal; Diabetes; Peso; Glucosa en sangre; Hormonas sexuales.

\section{REFERENCES}

Anderson, K. J.; Teuber, S. S.; Gobeille, A.; Cremin, P.; Waterhouse, A.L. \& Steinberg, F. M. Walnut polyphenolics inhibit in vitro human plasma and LDL oxidation. J. Nutr., 131(11):2837-42, 2001.

Bancroft, J. D. \& Marilyn, G. Theory and practice of histological techniques. $5^{\text {th }}$ ed. London, Churchill Livingstone, 2002. pp.345-50.

Fukuda, T.; Ito, H. \& Yoshida, T. Antioxidative polyphenols from walnuts (Juglans regia L.). Phytochemistry, 63(7):795-801, 2003.

Golalipour, M. J.; Jahanshahi, M.; Ghafari, S. \& Afshar, M. The preventive and treatment effect of Urtica dioica on astrocyte density in the CA1 and CA3 subfields of hippocampus in STZ induced diabetic rats. Int. J. Morphol., 31(2):693-9, 2013.
Kianifard, D.; Sadrkhanlou, R. \& Hasanzadeh, S. The histological, histomorphometrical and histochemical changes of testicular tissue in the metformin treated and untreated streptozotocin-induced adult diabetic rats. Vet. Res. Forum, 2(1):13-24, 2011.

Kim, M. J.; Ryu, G. R.; Chung, J. S.; Sim, S. S.; Min, D. S.; Rhie, D. J.; Yoon, S. H.; Hahn, S. J.; Kim, M. S. \& Jo, Y. H. Protective effects of epicatechin against the toxic effects of streptozotocin on rat pancreatic islets: in vivo and in vitro. Pancreas, 26(3):292-9, 2003.

Komolafe, O. A.; Ofusori, D. A.; Adewole, O. S.; Ayoka, A. O. \& Bejide, R. Histological and histochemical studies of the aorta and pulmonary trunk in STZ-induced diabetic Wistar rats treated with Momordica charantia. Int. J. Morphol., 31(2):716$23,2013$. 
Kris-Etherton, P. M.; Yu-Poth, S.; Sabaté, J.; Ratcliffe, H. E.; Zhao, G. \& Etherton, T. D. Nuts and their bioactive constituents: effects on serum lipids and other factors that affect disease risk. Am. J. Clin. Nutr., 70(3 Suppl.):504-11, 1999.

Labuckas, D. O.; Maestri, D. M.; Perelló, M.; Martínez, M. L. \& Lamarque, A. L. Phenolics from walnut (Juglans regia L.) kernels: Antioxidant activity and interactions with proteins. Food Chem., 107(2):607-12, 2008.

Lavedrine, F.; Ravel, A.; Villet, A.; Ducros, V. \& Alary, J. Mineral composition of two walnut cultivars originating in France and California. Food Chem., 68(3):347-51, 2000.

Ma, Y.; Njike, V. Y.; Millet, J.; Dutta, S.; Doughty, K.; Treu, J. A. \& Katz, D. L. Effects of walnut consumption on endothelial function in type 2 diabetic subjects: a randomized controlled crossover trial. Diabetes Care, 33(2):227-32, 2010.

Maneesh, M.; Jayalakshmi, H.; Singh, T. A. \& Chakrabarti, A. Impaired hypothalamic-pituitary-gonadal axis function in men with diabetes mellitus. Indian J. Clin. Biochem., 21(1):165-8, 2006.

Martínez, M. L.; Mattea, M. A. \& Maestri, D. M. Varietal and crop year effects on lipid composition of walnut (Juglans regia) genotypes. J. Am. Oil Chem. Soc., 83(9):791-6, 2006.

Mogulkoc, R.; Baltaci, A. K.; Aydin, L.; Oztekin, E. \& Tuncer, I. Pinealectomy increases oxidant damage in kidney and testis caused by hyperthyroidism in rats. Cell Biochem. Funct., 24(5):449-53, 2006.

Palmeira, C. M.; Santos, D. L.; Seiça, R.; Moreno, A. J. \& Santos, M. S. Enhanced mitochondrial testicular antioxidant capacity in Goto-Kakizaki diabetic rats: role of coenzyme Q. Am. J. Physiol. Cell Physiol., 281(3):1023-8, 2001.

Paz, G. \& Homonnai, Z. T. Leydig cell function in streptozotocininduced diabetic rats. Experientia, 35(10):1412-3, 1979.

Pereira, J. A.; Oliveira, I.; Sousa, A.; Valentão, P.; Andrade, P. B.; Ferreira, I. C.; Ferreres, F.; Bento, A.; Seabra, R. \& Estevinho, L. Walnut (Juglans regia L.) leaves: phenolic compounds, antibacterial activity and antioxidant potential of different cultivars. Food Chem. Toxicol., 45(11):2287-95, 2007.

Prasad, R. B. N. Walnuts and pecans. In: Caballero, B.; Trugo, L. C. \& Finglas, P. M. (Eds.). Encyclopedia of Food Sciences and Nutrition. London, Academic Press, 2003. pp.6071-9.

Seethalakshmi, L.; Menon, M. \& Diamond, D. The effect of streptozotocin-induced diabetes on the neuroendocrine-male reproductive tract axis of the adult rat. J. Urol., 138(1):190-4, 1987.

Stanciu, I.; Abboud, A.; Kellman, W.; Williams, D. \& Azad, N. Correlation of aging and body mass index with the hypothalamic-pituitary-gonadal axis hormones in men, with diabetes mellitus. Open Androl. J., 2:6-10, 2010.

Shenoy, A. G. \& Goyal, R. K. Improvement of insulin sensitivity by perindopril in spontaneously hypertensive and streptozotocin-diabetic rats. Indian J. Pharmacol., 34(3):15664, 2002.

Ward, D. N.; Bousfield, G. R. \& Moore, K. H. Gonadotropins. In: Cupps, P. T. (Ed.). Reproduction in Domestic Animals. San Diego, Academic Press, 1991. pp.25-67.

Williams, G. \& Pickup, J. C. Handbook of Diabetes. 3rd ed. Oxford, Blackwell Publishing, 2004. pp.48-60.

Zhang, Z.; Liao, L.; Moore, J.; Wu, T. \& Wang, Z. Antioxidant phenolic compounds from walnut kernels (Juglans regia L.). Food Chem., 113(1):160-5, 2009.

\author{
Correspondence to: \\ Dr. Cyrus Jalili \\ Fertility and Infertility Research Center \\ Medical School \\ Kermanshah University of Medical Sciences \\ Kermanshah, I.R. \\ IRAN
}

Email: cjalili@yahoo.com

Received: 19-05-2013

Accepted: 03-02-2014 